\title{
Evaluation of the bacteria formulation different inoculum densities on growth and development of Euphorbia pulcherrima
}

\author{
Fazilet Parlakova Karagöz*
}

Department of Horticulture, Faculty of Agriculture, Atatürk University, TR-25240 Erzurum, Turkey

\begin{abstract}
This research was carried out to examine the effects of different doses of bacterial formulation comprised of a mixture of Bacillus megaterium TV-91C, Pantoea agglomerans RK-92 and Kluyvera cryocrescens TV-113C strains on the plant development and bract quality of poinsettias (Euphorbia pulcherrima Willd. ex Klotzsch), which are one of the most important potted plants grown for their fleshy bracts of the horticultural sector. The study was carried out in a climatecontrolled research greenhouse from 8 August 2018 to 15 January 2019 in Erzurum (Turkey). Rooted cuttings of poinsettia [E. pulcherrima Willd. ex Klotzsch cv. Christmas Feelings $(\mathrm{CvF})]$ were used as plant materials in the study. Each of the solutions containing bacterial suspensions $52.5\left(\mathrm{~T}_{1}\right), 105\left(\mathrm{~T}_{2}\right), 210\left(\mathrm{~T}_{3}\right), 420\left(\mathrm{~T}_{4}\right)$ and $840\left(\mathrm{~T}_{5}\right) \mathrm{mL} \cdot \mathrm{L}^{-1}$ of water was diluted 5 times with water and $200 \mathrm{~mL} \cdot$ pot $^{-1}$ was applied to the plant rhizosphere. This study revealed that positive changes incurred in plant height, main flower stem length, plant crown width, bract diameter, green leaf and bract leaf area, leaf total nitrogen content and nitrate reductase enzyme activity parameters in poinsettia plants with increasing doses of the bacterial formulation. This effect has reached the maximum level in the number of bracts, main flower stem length, bract diameter, nitrate reductase enzyme activity, plant fresh weight and maximal root length parameters with the $\mathrm{T}_{5}$ application which has the highest bacterial formulation concentration. The most efficient application of glutamine synthetase enzyme activity was determined as $\mathrm{T}_{4}$.
\end{abstract}

Keywords: Euphorbia pulcherrima Willd. ex Klotzsch, fleshy bracts, glutamine synthetase activity, nitrate reductase activity, ornamental plant, poinsettia, rhizobacteria formulation

\section{INTRODUCTION}

Poinsettia (Euphorbia pulcherrima Willd. ex Klotzsch) is of high commercial importance (USDA, 2016) and one of the most popular ornamental indoor plants. Its popularity during Christmas and in indoor decorations is largely attributable to its flashy bract which remains viable throughout the winter season (Hu et al., 2019).

Plant growth is promoted with plant growthpromoting rhizobacteria (PGPR), which are one of the alternatives used in fertilisation programmes, friendly to the environment and the growing environment in plant breeding, biological $\mathrm{N}_{2}$ fixation, nutrient uptake from the rhizosphere, expansion of the root surface area, increasing beneficial host symbiosis (Vessey, 2003), increasing soluble phosphate intake and stimulating plant growth through iron uptake with the help of bacterial siderophores (Suhag, 2016).

The root activity of the cultured plants can be increased with phytosiderophore, enzymatic activities and rhizobial or mycorrhizal symbiosis (Couillerot et al., 2009). There are many studies in which the positive effects of a single use of PGPR strains are manifested on the growth and yield in the cultivation 
of many plant species (Mishra et al., 2010; Silva, 2011; Parlakova Karagöz et al., 2016; Karagöz et al., 2018; Zerrouk et al., 2019). There are also conclusions that two or more bacterial mixtures increase plant production more than single applications (Rojas et al., 2001). In previous studies, different formulations of different bacterial strains were applied to poinsettia in the bacterial concentrations of $10^{9}$ (Zulueta-Rodriguez et al., 2014) and $10^{8}$ cells $\cdot \mathrm{mL}^{-1}$ (Parlakova Karagöz and Dursun, 2019a) and significant results were obtained in terms of plant growth characteristics of the poinsettia.

No studies have been encountered in literature on whether the application of different doses of bacterial formulations effective on poinsettia has an impact on plant growth and its level of impact. Whereas bacterial inoculation density is an important factor in the agricultural applications of microbial inoculants. Many countries have dose standards for rhizobial inoculants (Bai et al., 2002). A limited number of studies have been carried out showing the effects of PGPR inoculation density on tomato (Pillay and Nowak, 1997), canola (Zablotowicz et al., 1991) and soybean (Zablotowicz et al., 1991; Bai et al., 2002).

Enzyme activity of plants, light intensity, photoperiod and photoperiod light time (Gebauer et al., 1984) vary according to the nitrogen form and the concentration of the soil (Geiger et al., 1999), plant species (Cousins and Bloom, 2003) and mycorrhizal association (Constable et al., 2001). Nitrate reductase (NR) is an enzyme that can be stimulated by its substrate, and any change in activity may reveal the presence of nitrate in the external environment of the plant (Arslan et al., 2009). Glutamine under the effect of glutamine synthetase enzyme; In the catalysis of glutamate synthase, it participates in glutamic acid structure and then takes a role in the formation of various amino acids. Plants exhibit better growth, photosynthesis activity, high total chlorophyll and carbohydrate concentration through these enzymes (Horchani et al., 2010).
The bract leaf area, which is one of the most important quality characteristics of the potted poinsettia, was increased by $8.52 \%$ with the treatment of bacterial formulation (Bacillus megaterium TV-91C, Pantoea agglomerans RK-92 and Kluyvera cryocrescens TV113C) (bacterial concentration of $10^{8}$ cells $\cdot \mathrm{mL}^{-1}$ ) according to control treatment in a study carried out by Parlakova Karagöz and Dursun (2019b). This study aimed to investigate the effect of different doses of the bacterial formulation on the growth and quality of the poinsettia, especially on the bract leaf area.

\section{MATERIALS AND METHODS}

The research was carried out in a climate-controlled research greenhouse from 8 August 2018 to 15 January 2019 in Erzurum (Turkey). Rooted cuttings of poinsettia [E. pulcherrima Willd. ex Klotzsch cv. Christmas Feelings $(\mathrm{CvF})]$ were used as plant materials in the study. The Christmas Feelings cultivar has red bracts. The cultivation medium was prepared by mixing peat and pumice (diameter: $10-30 \mathrm{~mm}$ ) as the volume in a ratio of 2:1. The plants were planted in $1.7 \mathrm{~L}(160 \times 150 \mathrm{~mm})$ plastic pots.

The treatments were different doses of B. megaterium TV-91C, P. agglomerans RK-92 and K. cryocrescens TV-113C formulation (Table 1). Each bacterial suspension (measured spectrophotometrically at $600 \mathrm{~nm}$ ) was properly diluted to $1 \times 10^{8} \mathrm{CFU} \cdot \mathrm{mL}^{-1}$ with distilled water. The rooted cuttings $(5-8 \mathrm{~cm})$ of the poinsettia were planted in pots filled with the appropriate growing medium on 8 August 2018. Each of the solutions containing bacterial suspensions 52.5, 105, 210,420 and $840 \mathrm{~mL} \cdot \mathrm{L}^{-1}$ of water (Table 2) was diluted fivefold and applied to the rhizosphere area at the rate of $200 \mathrm{~mL} \cdot$ pot $^{-1}$ on 21 September 2018. The amount of water where the need for a pot under the conditions in which this experiment was conducted was determined. In this amount, the bacterial solution $\left(200 \mathrm{~mL} \cdot \operatorname{pot}^{-1}\right)$

Table 1. Bacterial isolates used in the study and some biochemical properties (Kotan et al., 2014)

\begin{tabular}{lllllcc}
\hline Isolate No & MIS diagnosis result & SIM & Location (in Turkey) & Host & Nitrogen & Phosphate \\
\hline TV-91C & Bacillus megaterium & 0.474 & Van & Poaceae & + & W + \\
TV-113C & Kluyvera cryocrescens & 0.688 & Van & Garlic & + & + \\
RK-92 & Pantoea agglomerans & 0.889 & Erzurum & Pear & + & S \\
\hline
\end{tabular}

SIM, similarity index; s, strong +; w, weak +, +, positive; -, negative.

Table 2. Concentrations of bacterial formulation used in the study and their treatments codes

\begin{tabular}{lccc}
\hline Treatments & $\begin{array}{c}\text { The amount taken from the suspension of } \\
\text { each bacteria strain }(\mathrm{mL})\end{array}$ & $\begin{array}{c}\text { The total amount of formulation } \\
(\mathrm{mL})\end{array}$ & \begin{tabular}{c} 
The amount of water $(\mathrm{mL})$ \\
\hline Control
\end{tabular} $\mathrm{T}_{1}$ \\
$\mathrm{~T}_{1}$ & 17.5 & 0.0 & $1,000.0$ \\
$\mathrm{~T}_{2}$ & 35.0 & 52.5 & 947.5 \\
$\mathrm{~T}_{3}$ & 70.0 & 105.0 & 895.0 \\
$\mathrm{~T}_{4}$ & 140.0 & 210.0 & 790.0 \\
$\mathrm{~T}_{5}$ & 280.0 & 420.0 & 580.0 \\
\hline
\end{tabular}


was applied to each pot, and watering was not done again immediately after the application. The study was designed as three replicates in a completely randomised design. There were 15 potted plants in each replicate. No fertilisation was applied and irrigation was carried out according to the irrigation needs of the plants during the experiment.

The maximum and minimum temperatures and relative humidity in the research greenhouse were monitored by using a Digital Temperature Humidity Meter (Loobex Htc-2). The temperature inside the research greenhouse ranged between 10.79 and $39.45^{\circ} \mathrm{C}$. The relative humidity was in the range of $11.33-84.86 \%$.

After 155-160 days from bacterial inoculation (Figure 1), the vegetative growth of the poinsettia plants (diameter of stems, chlorophyll content, green and bract leaf area, plant fresh and dry weight, number of roots, root diameter and length, root fresh and dry weight) were recorded. The measurements were taken on the plants when they reached the optimum marketing (sales) time. The stem diameter was measured immediately below the first branch using a digital calliper. The chlorophyll content parameter was obtained by calculating the average of the readings taken by using the portable chlorophyll metre (SPAD-502, Minolta, Japan) on five plants and five different leaves of each plant. The leaf area was measured using a CI 202 Portable Digital Brand Leaf Area Meter. The plant roots were washed and the growing medium was removed. After washing, the roots of five plants from each repetition of each application were examined. Two longest roots from each plant were collected at random and their diameters measured. The root diameter was averaged along the root. The two longest roots of a plant were counted and the longest root length was measured and the average was taken. Plant and root tissue samples were oven-dried at $68^{\circ} \mathrm{C}$ for $48 \mathrm{~h}$, ground, and passed through a 1-mm sieve. The Vapodest 10 Rapid Kjeldahl Distillation Unit (Gerhardt, Germany) and the Kjeldahl method were used to determine the total $\mathrm{N}$ (Bremner, 1996) in the growth medium, plant and root.

The nitrate reductase (NR) assay followed the method according to $\mathrm{Yu}$ and Zhang (2012) with slight modifications. About $30 \mathrm{mg}$ bract leaves were homogenised with $1 \mathrm{~mL}$ of $0.1 \mathrm{M}$ HEPES$\mathrm{KOH}$ buffer solution ( $\mathrm{pH} \quad 7.5)$ containing $3 \%$ (w/v) polyvinylpolypyrrolidone (PVPP), $1 \mathrm{mM}$ ethylenediaminetetraacetic acid (EDTA) and $7 \mathrm{mM}$ cysteine. The homogenate was centrifuged for $10 \mathrm{~min}$ at $10,000 \mathrm{~g}$ at $4^{\circ} \mathrm{C}$, and the supernatant was used for NR activity analysis according to the methods described by several previous reports (Jonassen et al., 2008; Zhang et al., 2011). The NR activity was calculated as mol $\mathrm{NO}_{2}^{-}$produced per hour and gram of fresh weight (mol $\mathrm{NO}_{2} \cdot \mathrm{g}^{-1} \cdot \mathrm{FWh}^{-1}$ ). For Glutamine synthetase activity (GSA) assay, the bract leaf samples were extracted with $0.5 \mathrm{mmol} \cdot \mathrm{L}^{-1}$ EDTA and $50 \mathrm{mmol} \cdot \mathrm{L}^{-1} \mathrm{~K}_{2} \mathrm{SO}_{4}$. The homogenates were centrifuged at 20,000 $\mathrm{g}$ for $20 \mathrm{~min}$. Then, $1.2 \mathrm{~mL}$ of the clear filtrate was added to a centrifuge tube, followed by $0.6 \mathrm{~mL}$ imidazole $-\mathrm{HCl}(\mathrm{pH}$ $\left.7.0 ; 0.25 \mathrm{~mol} \cdot \mathrm{L}^{-1}\right), 0.4 \mathrm{~mL}$ sodium glutamate $(\mathrm{pH} 7.0$; $\left.0.3 \mathrm{~mol} \cdot \mathrm{L}^{-1}\right), 0.4 \mathrm{~mL}$ ATP-Na $\left(\mathrm{pH} 7.0 ; 15 \mathrm{mmol} \cdot \mathrm{L}^{-1}\right)$, $0.2 \mathrm{~mL} \mathrm{MgSO}_{4}\left(0.5 \mathrm{~mol} \cdot \mathrm{L}^{-1}\right)$ and $0.2 \mathrm{~mL}$ hydroxylamine $\left(1 \mathrm{~mol} \cdot \mathrm{L}^{-1}\right)$. After the mixture was incubated at $25^{\circ} \mathrm{C}$ for $20 \mathrm{~min}$, the reaction was terminated by adding $0.8 \mathrm{~mL}$ acidic $\mathrm{FeCl}_{3}[24 \%(\mathrm{w} / \mathrm{v})$ trichloroacetic acid and 10\% (w/v) $\mathrm{FeCl}_{3}$, in $18 \% \mathrm{HCl}$ ]. The production of $\gamma$-glutamyl hydroxamate was measured with a spectrophotometer at $540 \mathrm{~nm}$. One unit of GSA was defined as the enzyme catalysing the formation of $1 \mathrm{mmol} \gamma$-glutamyl hydroxamate per minute at $25^{\circ} \mathrm{C}$ (Zhang et al., 1997; Liu et al., 2013). One unit of GS activity was expressed in $\mu \mathrm{mol} \mathrm{GHA} \cdot \mathrm{h}^{-1}$.

The statistical analysis was made using SPSS. The data were subjected to analysis of variance, then the means were separated by using Duncan' Multiple Range Test $(p<0.05)$. For graphic creation of data of some parameters, the SigmaPlot 12 (Systat Software Inc) was used.

\section{RESULTS}

Significant differences were observed between treatments in terms of the evaluated plant growth parameters. The highest number of green leaves (7.92 number $\cdot$ plant $^{-1}$ ) was obtained in the $\mathrm{T}_{5}$ treatment and the $\mathrm{T}_{2}, \mathrm{~T}_{3}$ and $\mathrm{T}_{4}$ treatments were statistically in the same group. The highest bract leaves number (12.42 number $\cdot$ plant $\left.^{-1}\right)$, plant height $(24.99 \mathrm{~cm})$ and main
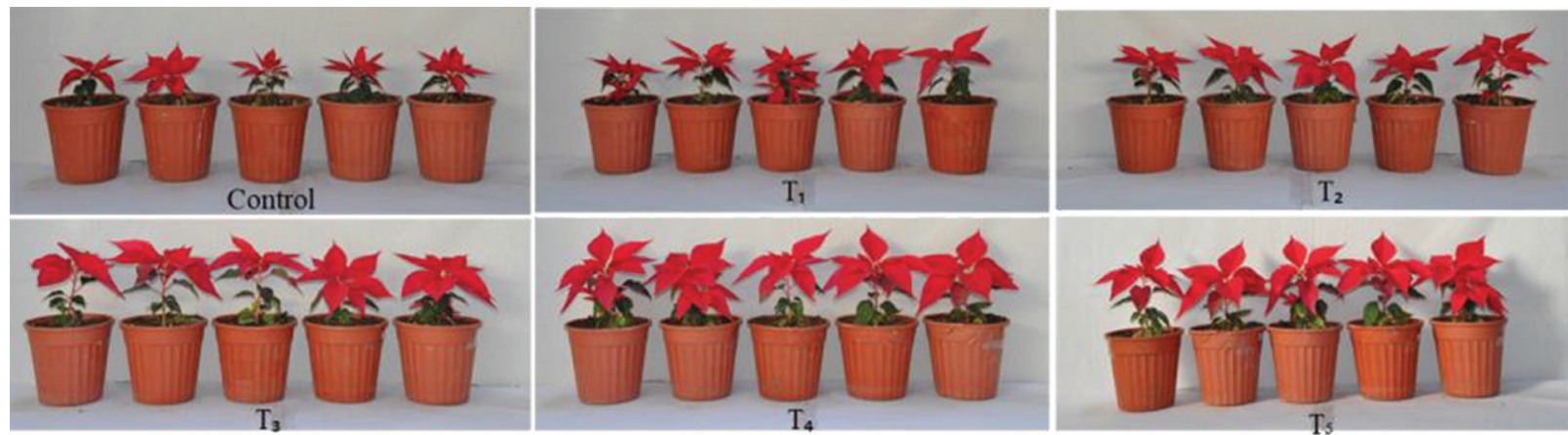

Figure 1. The appearance of (different concentrations of bacterial formulation)-treatment and control plants on day 160. 
flower stalk length $(12.49 \mathrm{~cm})$ were obtained with the $\mathrm{T}_{5}$ treatment. The highest values of the bract leaves number, plant height and main flower stalk length parameters were obtained with the $\mathrm{T}_{5}$ treatment by increase rate $34.27,42.07$ and $58.70 \%$, respectively when compared with the control treatment. In terms of the size of the plant crown, the highest value was found in the $\mathrm{T}_{5}$ treatment with $18.10 \mathrm{~cm}$; however, the $\mathrm{T}_{5}$ treatment was in the same statistical group as $\mathrm{T}_{3}(16.30 \mathrm{~cm})$ and $\mathrm{T}_{4}(16.55 \mathrm{~cm})$ treatments for this parameter (Table 3).

The highest values for bract diameter $(25.33 \mathrm{~cm})$ (Table 4) and root dry weight (1.27 g $\cdot$ plant $\left.^{-1}\right)$ (Figure 2) were also determined in the $\mathrm{T}_{5}$ treatment. It was determined that the increases obtained for these parameters were higher at rate $32.48,136.81$ and $67.11 \%$, respectively, when compared with the control treatment. The increases in chlorophyll were obtained in all treatments compared to the control treatment but were not significantly different among treatments (Table 4). The highest values for green leaf area and bract area were determined in the $\mathrm{T}_{4}$ and $\mathrm{T}_{5}$ treatments. The green leaf area increased by 72.73 and $79.98 \%$ with the $\mathrm{T}_{4}$ and $\mathrm{T}_{5}$ treatments, respectively while the bract area increased by 29.47 and $29.97 \%$, respectively when compared to the control treatment (Table 4).

According to the control application, the effects of treatments on the main stem diameter was not statistically significant $(p>0.05)$ (Table 4$)$. The effects of treatments on root length, root number, root diameter and root fresh weight were not statistically significant $(p>0.05)$ (Figure 2).

All bacterial applications increased nitrate reductase activity (NRA) in leaves compared to control. This increase was more pronounced in $T_{5}$ treatment. Furthermore, there were no significant differences in NRA in terms of $\mathrm{T}_{2}$ and $\mathrm{T}_{4}$ treatments (Table 5).

Glutamine synthetase (GS) activity was significantly increased with $\mathrm{T}_{4}$ compared with the control group. GS activity in plants grown with $\mathrm{T}_{3}$ manifested the secondhighest and the third-highest GSA was observed in plants grown with $\mathrm{T}_{5}$. But no significant difference between them (T3 and T5). Also, there was no significant difference in GS activity among $T_{1}, T_{2}$ and control groups (Table 5).

In the observations described above, the highest total $\mathrm{N}$ content in leaf samples was present with $\mathrm{T}_{5}$ $\left(6.90 \mathrm{mg} \cdot \mathrm{kg}^{-1}\right)$ and $\mathrm{T}_{2}\left(6.80 \mathrm{mg} \cdot \mathrm{kg}^{-1}\right)$. There was no

Table 3. Differences in the green leaves number, bract leaves number, plant height, main flower stalk length and size of bract crown of poinsettias subject to different doses of PGPR formulation in the pot experiment

\begin{tabular}{lllccc}
\hline Treatments & Green leaves (no.) & Bract leaves (no.) & Plant height $(\mathrm{cm})$ & $\begin{array}{c}\text { Main flower stalk } \\
\text { length }(\mathrm{cm})\end{array}$ & $\begin{array}{c}\text { Size of bract crown } \\
(\mathrm{cm})\end{array}$ \\
\cline { 2 - 6 } & & \multicolumn{5}{c}{ Means $\pm \mathrm{SD}$} \\
\hline Control & $4.92 \pm 0.58 \mathrm{bc} *$ & $9.25 \pm 1.09 \mathrm{~cd}^{* * *}$ & $17.59 \pm 1.18 \mathrm{~cd}^{* *}$ & $7.87 \pm 0.62 \mathrm{~cd} * *$ & $13.38 \pm 1.16 \mathrm{~b}^{* *}$ \\
$\mathrm{~T}_{1}$ & $4.47 \pm 1.79 \mathrm{c}$ & $7.22 \pm 0.84 \mathrm{e}$ & $15.87 \pm 1.87 \mathrm{~d}$ & $7.33 \pm 1.98 \mathrm{~d}$ & $12.30 \pm 2.23 \mathrm{~b}$ \\
$\mathrm{~T}_{2}$ & $7.14 \pm 0.55 \mathrm{a}$ & $8.36 \pm 0.88 \mathrm{de}$ & $16.85 \pm 1.28 \mathrm{~d}$ & $8.03 \pm 0.79 \mathrm{~cd}$ & $13.68 \pm 2.12 \mathrm{~b}$ \\
$\mathrm{~T}_{3}$ & $6.03 \pm 0.68 \mathrm{abc}$ & $10.92 \pm 0.88 \mathrm{~b}$ & $19.35 \pm 1.24 \mathrm{c}$ & $9.55 \pm 1.06 \mathrm{bc}$ & $16.30 \pm 1.17 \mathrm{a}$ \\
$\mathrm{T}_{4}$ & $6.75 \pm 0.90 \mathrm{ab}$ & $10.36 \pm 0.38 \mathrm{bc}$ & $21.93 \pm 1.05 \mathrm{~b}$ & $11.37 \pm 1.02 \mathrm{ab}$ & $16.55 \pm 0.35 \mathrm{a}$ \\
$\mathrm{T}_{5}$ & $7.92 \pm 1.46 \mathrm{a}$ & $12.42 \pm 0.80 \mathrm{a}$ & $24.99 \pm 0.80 \mathrm{a}$ & $12.49 \pm 0.85 \mathrm{a}$ & $18.10 \pm 0.15 \mathrm{a}$ \\
\hline Mean & $6.20 \pm 1.55$ & $9.75 \pm 1.89$ & $19.43 \pm 3.42$ & $9.44 \pm 2.19$ & $15.05 \pm 2.43$ \\
\hline
\end{tabular}

Different letters in the same column indicate significant differences $(p<0.05)$ based on Duncan's multiple range test.

$\mathrm{SD}$, standard deviation.

$*, * *, * * *$ significant at $p \leq 0.05,0.01$, or 0.001 , respectively.

Table 4. The effect of different doses of PGPR formulation on bract diameter, main stem diameter, relative chlorophyll content, green leaf and bract leaf area in the pot experiment

\begin{tabular}{llcccc}
\hline Treatments & $\begin{array}{c}\text { Bract diameter } \\
(\mathrm{cm})\end{array}$ & $\begin{array}{c}\text { Main stem diameter } \\
(\mathrm{mm})\end{array}$ & $\begin{array}{c}\text { Relative chlorophyll } \\
\text { content }(\mathrm{SPAD})\end{array}$ & $\begin{array}{c}\text { Green leaf area } \\
\left(\mathrm{cm}^{2}\right)\end{array}$ & $\begin{array}{c}\text { Bract leaf area } \\
\left(\mathrm{cm}^{2}\right)\end{array}$ \\
\cline { 2 - 6 } & & & Means $\pm \mathrm{SD}$ & \\
\hline Control & $19.12 \pm 1.46 \mathrm{bc}$ & $4.42 \pm 0.23 \mathrm{~ns}$ & $42.00 \pm 2.76 \mathrm{~b}^{*}$ & $10.34 \pm 0.74 \mathrm{c}^{* * *}$ & $67.16 \pm 9.04 \mathrm{c}^{* *}$ \\
$\mathrm{~T}_{1}$ & $16.95 \pm 2.14 \mathrm{c}$ & $4.93 \pm 0.42$ & $52.67 \pm 2.46 \mathrm{a}$ & $8.66 \pm 1.10 \mathrm{c}$ & $77.56 \pm 2.36 \mathrm{~b}$ \\
$\mathrm{~T}_{2}$ & $18.23 \pm 2.90 \mathrm{bc}$ & $5.00 \pm 0.45$ & $50.27 \pm 1.12 \mathrm{a}$ & $9.86 \pm 0.76 \mathrm{c}$ & $78.07 \pm 2.24 \mathrm{~b}$ \\
$\mathrm{~T}_{3}$ & $19.45 \pm 4.33 \mathrm{bc}$ & $5.19 \pm 0.40$ & $49.97 \pm 6.07 \mathrm{a}$ & $15.14 \pm 0.93 \mathrm{~b}$ & $78.53 \pm 2.14 \mathrm{~b}$ \\
$\mathrm{~T}_{4}$ & $22.13 \pm 0.51 \mathrm{ab}$ & $4.73 \pm 0.73$ & $50.27 \pm 2.18 \mathrm{a}$ & $17.86 \pm 1.51 \mathrm{a}$ & $86.95 \pm 1.77 \mathrm{a}$ \\
$\mathrm{T}_{5}$ & $25.33 \pm 0.63 \mathrm{a}$ & $5.45 \pm 0.16$ & $48.73 \pm 1.17 \mathrm{a}$ & $18.61 \pm 1.39 \mathrm{a}$ & $87.29 \pm 0.99 \mathrm{a}$ \\
\hline Mean & $20.20 \pm 3.49$ & $4.95 \pm 0.50$ & $48.98 \pm 4.31$ & $13.41 \pm 4.19$ & $79.26 \pm 7.77$ \\
\hline
\end{tabular}

Different letters in the same column indicate significant differences $(p<0.05)$ based on Duncan's multiple range test.

ns, non-significant; SD, standard deviation.

$*, * *, * * *$ significant at $p \leq 0.05,0.01$, or 0.001 , respectively. 
significant difference between treatments in terms of total nitrogen content in the roots samples. The highest values for plant fresh weight $\left(37.89 \mathrm{~g} \cdot\right.$ plant $\left.^{-1}\right)$ were also determined in the $T_{5}$ treatment. The highest value for plant dry weight (Table 6) was determined in the $\mathrm{T}_{4}$ and $\mathrm{T}_{5}$ treatments. Plant dry weight increased by $85.94 \%$ and $137.11 \%$ in $\mathrm{T}_{4}$ and $\mathrm{T}_{5}$ treatments compared to the control treatment (Table 6).

\section{DISCUSSION}

The long-term preservation of colour and form characteristics of ornamental plants is an important criterion for the acceptance of indoor ornamental plants as a decorative element (Karunananda and Peiris, 2011). A study carried out by Acar et al. (2003) revealed that after the colour feature of ornamental plants, buyers

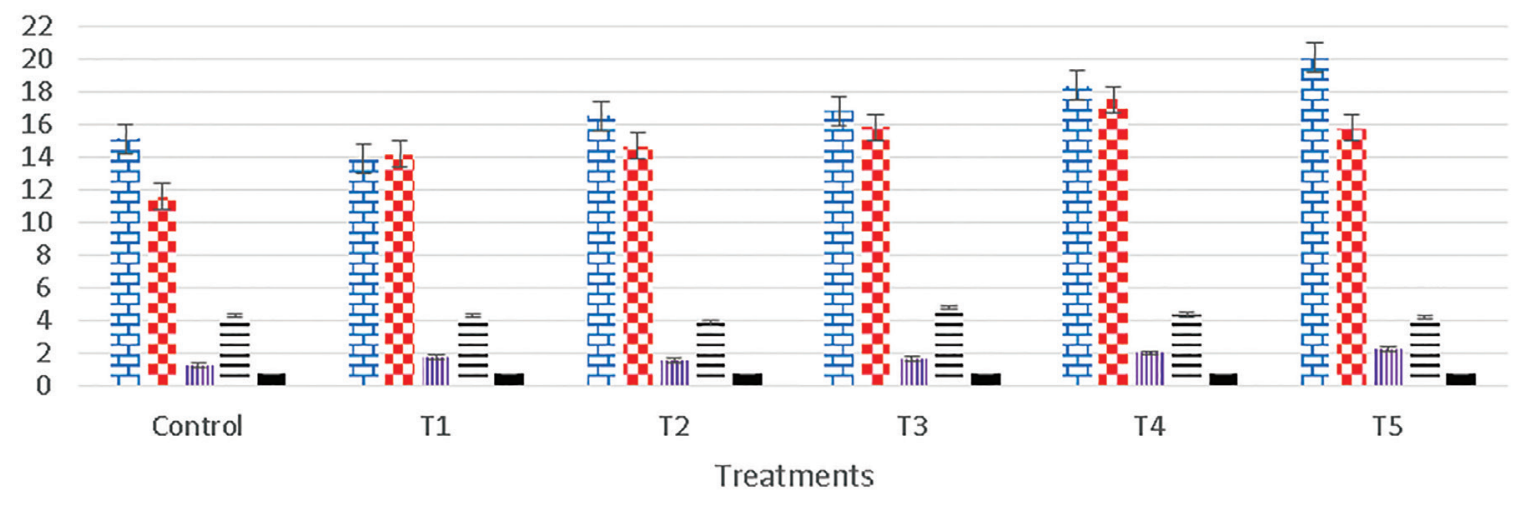

$$
\begin{aligned}
& \text { ב Maximal root length }(\mathrm{mm}) \\
& \text { IIII Root diameter }(\mathrm{mm}) \\
& \text { - Root dry weight (g per plant) }
\end{aligned}
$$$$
\square \text { Numbers of adventitious root (per plant) }
$$$$
\text { - Root fresh weight (g per plant) }
$$

Figure 2. Differences in the root parameters of poinsettia subject to different doses of PGPR formulation. Error bars represent SD and data in the graphs are the means \pm standard deviation.

Table 5. The effect of different doses of PGPR formulation on NRA and GS activity in the pot experiment

\begin{tabular}{lll}
\hline Treatments & NRA $\left(E U \mathrm{~g} \cdot\right.$ tissue $\left.^{-1}\right)$ & GS $\left(\mu \mathrm{mol} \gamma\right.$-glutamyl hydroxamate formed $\left.\cdot \mathrm{g}^{-1} \cdot \mathrm{min}^{-1}\right)$ \\
\cline { 2 - 3 } & \multicolumn{3}{c}{ Means $\pm \mathrm{SD}$} \\
\hline Control & $4.03 \pm 0.98 \mathrm{~d} * * *$ & $0.23 \pm 0.01 \mathrm{c} * * *$ \\
$\mathrm{~T}_{1}$ & $6.32 \pm 0.70 \mathrm{c}$ & $0.23 \pm 0.00 \mathrm{c}$ \\
$\mathrm{T}_{2}$ & $6.99 \pm 0.31 \mathrm{bc}$ & $0.23 \pm 0.00 \mathrm{c}$ \\
$\mathrm{T}_{3}$ & $7.89 \pm 0.94 \mathrm{~b}$ & $0.26 \pm 0.01 \mathrm{~b}$ \\
$\mathrm{~T}_{4}$ & $7.07 \pm 0.98 \mathrm{bc}$ & $0.27 \pm 0.01 \mathrm{a}$ \\
$\mathrm{T}_{5}$ & $9.63 \pm 0.46 \mathrm{a}$ & $0.25 \pm 0.01 \mathrm{~b}$ \\
\hline Mean & $6.99 \pm 1.85$ & $0.24 \pm 0.01$ \\
\hline
\end{tabular}

Different letters in the same column indicate significant differences $(p<0.05)$ based on Duncan's multiple range test.

$\mathrm{SD}$, standard deviation.

$* * *$ significant at $p \leq 0.001$.

Table 6. The effect of different doses of PGPR formulation on plant fresh and dry weight, the total nitrogen content of leaf and root in the pot experiment

\begin{tabular}{lcccc}
\hline Treatments & Plant fresh weight $\left(\mathrm{g} \cdot\right.$ plant $\left.^{-1}\right)$ & Plant dry weight $\left(\mathrm{g} \cdot\right.$ plant $\left.^{-1}\right)$ & Total N of leaf $(\%)$ & Total N of root $(\%)$ \\
\cline { 2 - 5 } & \multicolumn{4}{c}{ Means \pm SD } \\
\hline Control & $16.00 \pm 3.69 \mathrm{c}^{* * *}$ & $2.56 \pm 0.68 \mathrm{~b}^{* * *}$ & $5.84 \pm 0.13 \mathrm{c}^{* * *}$ & $1.85 \pm 0.05^{\mathrm{ns}}$ \\
$\mathrm{T}_{1}$ & $17.81 \pm 4.94 \mathrm{c}$ & $2.91 \pm 1.04 \mathrm{~b}$ & $6.47 \pm 0.07 \mathrm{~b}$ & $1.90 \pm 0.03$ \\
$\mathrm{~T}_{2}$ & $14.10 \pm 3.09 \mathrm{c}$ & $2.54 \pm 0.80 \mathrm{~b}$ & $6.80 \pm 0.06 \mathrm{a}$ & $1.85 \pm 0.04$ \\
$\mathrm{~T}_{3}$ & $20.08 \pm 4.23 \mathrm{c}$ & $3.29 \pm 0.71 \mathrm{~b}$ & $5.12 \pm 0.30 \mathrm{e}$ & $1.86 \pm 0.03$ \\
$\mathrm{~T}_{4}$ & $28.86 \pm 4.47 \mathrm{~b}$ & $4.76 \pm 0.82 \mathrm{a}$ & $5.46 \pm 0.24 \mathrm{~d}$ & $1.90 \pm 0.07$ \\
$\mathrm{~T}_{5}$ & $37.89 \pm 4.80 \mathrm{a}$ & $6.07 \pm 0.21 \mathrm{a}$ & $6.90 \pm 0.06 \mathrm{a}$ & $1.95 \pm 0.04$ \\
\hline Mean & $22.46 \pm 9.30$ & $3.69 \pm 1.48$ & $6.10 \pm 0.70$ & $1.88 \pm 0.06$ \\
\hline
\end{tabular}

Different letters in the same column indicate significant differences $(p<0.05)$ based on Duncan's multiple range test.

ns, non-significant; SD, standard deviation.

$* * *$ significant at $p \leq 0.001$. 
made their choices mainly according to form features. In our study, it was concluded that in the single stem cultivation (Fisher et al., 1996) of poinsettia varieties, increasing doses of bacteria formulation resulted in more compact and pot filling plants with better form in terms of the maximum number of green and bract leaves, plant crown width, bract diameter, green leaf and bract leaf area. Zulueta-Rodriguez et al. (2014) emphasised that Pseudomonas putida rhizobacteria were effective in increasing the number of leaves of poinsettia varieties. These results can be explained depending on the intake of nutrients in the growing medium, type and the number of microorganisms that the plant can use and transform into form.

Similar increases in the diameter of the main stem of poinsettias presented in this study have been reported in numerous studies as a result of the inoculation of Azospirillum, Pseudomonas and Azotobacter strains into different plant species (Kokalis-Burelle et al., 2002; Shaukat et al., 2006; Chattha et al., 2017). As a result of our study, the applications increased the diameter of the main stem, which supports these findings. Furthermore, the increase in the maximum diameter of the main stem was achieved with the applications of increasing concentration of bacterial formulation.

Previous studies have reported that the application of P. fuorescens Pf5 rhizobacteria increased the blueberry stalk length (De Silva et al., 2000), the formulation of P. agglomerans, B. megaterium and Paenibacillus polymyxa bacteria increased the length of the tulip stem (Parlakova Karagöz and Dursun, 2019c) and the application of irrigation+PGPR increased the length of wheat spike stems (Pazouki, 2016). The main reason for obtaining the longest stalk length with the $\mathrm{T}_{5}$ treatment of poinsettia cultivars grown under the same conditions is attributed to the addition of a higher dose of bacterial formulation to the growing environment and the bacteria in the formulation content being more effective in separating the nutrients and synthesising growthpromoting substances.

Ge et al. (2016) reported that the application of Bacillus methylotrophicus NKG-1 bacteria strain increased the crown width of tomato seedlings by $16.3 \%$. Rachmawati and Korlina (2016) asserted that the highest dose of biological fertiliser enriched with PGPRs played a role in increasing the crown width of Brassica juncea. In this study, the poinsettia's crown width parameter was determined in the $T_{5}$ treatment, which had the highest concentration of bacteria formulation.

It is known that as a result of the inoculation of ornamental plants, forest trees, vegetables and agricultural products with PGPR, seedling germination, plant height, shoot weight, nutrient and chlorophyll content increases (Lazarovits, 1995; Glick et al., 1999; Saharan and Nehra, 2011). Das (2010) reported that PGPRs are effective in increasing the chlorophyll content of the Vinca rosea plant. In this study, the chlorophyll content also increased in treatments compared to the control treatment. However, this parameter was not affected by increasing doses of the bacterial formulation. The fresh and dry shoot weights of 'Peterstar' and 'Maren' poinsettia varieties treated with commercial biofertilizer (Ores, PSBIO System, Italy) and nitrogen fertiliser $\left(\mathrm{NH}_{4} \mathrm{NO}_{3}\right)$ containing Rhodobacter capsulatus bacteria at doses of 0.75 and $1.5 \mathrm{~mL} \cdot \mathrm{L}^{-1}$ have been reported to increase (Martinetti et al., 2007). The results of this study paralleled those of Martinetti et al. (2007).

The intake of nutrients in the growing environment and the type and quantity of microorganisms among the applications are determined to be the reasons for the differences incurred in leaf areas. As a matter of fact, in many studies, there are definitions of PGPRs that stimulate the development of plant organs by improving cell division and expansion (Taiz and Zeiger, 2002) or nutrient uptake (Lazarovits, 1995; Glick et al., 1999; Saharan and Nehra, 2011; Nguyen et al., 2019). Besides, the PGPR applications have been reported to increase the blueberry leaf area (De Silva et al., 2000), tulip leaf area (Parlakova Karagöz and Dursun, 2019c), banana leaf area (Baset et al., 2010), soybean leaf area (Han and Lee, 2005), cabbage seedling leaf area (Turan et al., 2014), maize leaf area (Gholami et al., 2009), canola leaf area (Zablotowicz et al., 1991) and the area of poinsettia leaves (Zulueta-Rodriguez et al., 2014). The findings of this study are compatible with this literature. As a result of this study, it has been determined that increasing the leaf area parameter could be realised by applying increasing doses of PGPR.

Macias et al. (2010) studied the effect of different growing environments on the bract diameter and obtained bract leaf diameters ranging between 12.8 and $22.1 \mathrm{~cm}$. The bract leaf diameter values obtained in this study were determined to be between 16.95 and $25.33 \mathrm{~cm}$. The study carried out by Martinetti et al. (2007) revealed that commercial biofertilizer treatments supplemented with 0.75 and $1.5 \mathrm{~mL} \cdot \mathrm{L}^{-1}$ adjusted of $R$. capsulatus bacteria (compared to control $+6 \%$ ) increased the diameter of the poinsettia 'Peterstar' variety and that the bract leaf diameters ranged from $16.6 \mathrm{~cm}$ to $18.3 \mathrm{~cm}$. It was concluded that the results of our study were in line with these results and our treatments increased the bract diameter more.

According to Paul and Clark (1996), microorganisms in soil are involved in biogeochemical cycles such as the decomposition of organic matter, humus formation, nutrient conversion and fixation of atmospheric nitrogen. Bacteria change root morphology and increase biomass; thus, it is possible to benefit more from soil volume and receive soil nutrients (Fierro-Coronado et al., 2014). The significant difference between plants treated with the $\mathrm{T}_{5}$ treatment and the control group and other dosages in terms of plant fresh weight and plant dry weight, total nitrogen content in leaves and root dry weight determined in this study can be explained with the results of the previous study. Furthermore, increasing 
the dose of bacterial formulation increased the root dry weight in this study.

Nitrogen, which is one of the most important nutrients that plants should take from the soil solution is an important factor that limits plant growth after water (Vitousek and Howarth, 1991). As shown in many previous studies, there is a strong association between nitrogen supply and the $\mathrm{CO}_{2}$ assimilation rate (Evans, 1989; Smart, 1994). Also, nitrogen availability is very important in leaf life. Many publications report that nitrogen deficiency can accelerate leaf yellowing and ageing (Smart, 1994; Pourtau et al., 2004; Kato et al., 2005). As a result of this research, the effect of the treatments on the total nitrogen content of green leaf was found to be statistically significant. PGPRs enable plants to get better nutrients and are known to provide better growth and higher yields by activating hormonal activity and obstructing naturally present harmful microflora in the roots (Altin and Bora, 2005). As a result of a study carried out by Arab et al. (2015) access to nitrogen and phosphorus elements dependent on the activity of Pseudomonas bacteria in the soil was increased. In the present study, the increase in the highest leaf nitrogen with the application of $\mathrm{T}_{5}$, which has the highest bacterial formulation concentration, was found to be consistent with this study result. However, statistically no significant difference with $\mathrm{T}_{2}$.

Nitrogen $(\mathrm{N})$ is taken from the soil by plants in $\mathrm{NO}_{3}{ }^{-}$and $\mathrm{NH}^{4+}$ forms (Hawkesford et al., 2012). Nitrate reductase (NR) in the cytoplasm of higher plants is a key enzyme involved in the reduction of $\mathrm{NO}_{3}$ ( $\mathrm{Hu}$ et al., 2014). The presence of nitrate in the medium is not an absolute condition for the expression of the NR gene (Tischner, 2000). However, since NR is an enzyme that can be stimulated by its substrate, change in activity may reveal the presence of nitrate in the external environment of the plant (Arslan et al., 2009). The application of $\mathrm{T}_{5}$ incurring the highest total nitrogen content and the highest NR activity determined in the leaf samples in this study confirms this situation.

In this study, it was determined that the NRA increased with increasing doses. It is concluded that this may be related to an increase in the concentration of bacteria in the growing medium (Geiger et al., 1999).

Ammonia formed as a result of the reduction of ammonium or nitrate taken by the roots is toxic to plant tissue and therefore should not be deposited but immediately enter organic structures (Barro et al., 1991). The introduction of ammonia into organic structures takes place through a mechanism called Glutamine synthetase-Glutamate synthase pathway (Marschner, 1995). In this way, under the activity of glutamine synthetase enzyme ammonia is added to the structure of glutamine and glutamic acid under the catalysis of glutamate synthase and then plays a role in the formation of various amino acids. As a result of our research, the most efficient application of glutamine synthetase enzyme activity was determined as $\mathrm{T}_{4}$. The increase in plant crown width in $\mathrm{T}_{3}, \mathrm{~T}_{4}$ and $\mathrm{T}_{5}$ treatments may also be related to glutamine synthetase enzyme. Horchani et al. (2010) reported that ammonium-fed tomato plants exhibited better growth, photosynthesis activity, high total chlorophyll and carbohydrate concentration.

In conclusion, it has been demonstrated that the previously tested application of a bacterial formulation comprised of a combination of $B$. megaterium TV91C, P. agglomerans RK-92 and K. cryocrescens TV$113 \mathrm{C}$ strains can be used successfully to improve plant growth and enhance plant aesthetics in the cultivation of poinsettias subject to the treatment rates. When the effect of increasing doses of the bacterial formulation was taken into consideration in the study, positive changes were manifested in plant height, main plant stem length, plant crown width, bract diameter, green leaf and bract leaf area, leaf total nitrogen content and NR enzyme activity parameters of poinsettia plants. This impact reached the maximum level in many parameters with the $\mathrm{T}_{5}$ treatment, which had the highest bacterial formulation concentration.

\section{ACKNOWLEDGEMENTS}

I thank Atilla Dursun (Atatürk University, Agriculture Faculty, Department of Horticulture, Erzurum, Turkey), Recep Kotan (Atatürk University, Agriculture Faculty, Department of Plant Protection, Erzurum, Turkey) and Ökkeş Atıcı (Department of Biology, Faculty of Science, Ataturk University, Erzurum, Turkey) who were involved in the experiment.

\section{FUNDING}

This work was not funded by any research funds.

\section{AUTHOR CONTRIBUTIONS}

F.P.K planned, conducted the experiment, wrote the manuscript, designed and performed statistical analysis.

\section{CONFLICT OF INTEREST}

The author declare that there are no potential conflicts of interest regarding the research, authorship and publication of this manuscript.

\section{REFERENCES}

Acar, C., Demirbaş, E., Dinçer, P., And Acar, H. (2003). Evaluation of semantic differantial scale technique for plant composition samples. S.D. $\ddot{U}$. Journal of Faculty of Forestry, 1, 15-28.

Altin, N., AND BorA, T. (2005). Common properties and effects of plant growth promoting rhizobacteria. ANADOLU Journal of Aegean Agricultural Research Institute, 15(2), 87-103.

Arab, A., Zamani, G. R., Sayyari, M. H., and Asili, J. (2015). Effects of chemical and biological fertilizers on morpho-physiological traits of marigold 
(Calendula officinalis L.). European Journal of Medicinal Plants, 8(1), 60-68.

Arslan, H., Kirmizi, S., Sakar, S., and Güleryüz, G. (2009). Nitrate reductase activity (NRA) in some shrub species from Mediterranean Environment. Ekoloji, 18, 49-56.

Bai, Y., Pan, B., Charles, T. C., and Smith, D. L. (2002). Co-inoculation dose and root zone temperature for plant growth promoting rhizobacteria on soybean [Glycine max (L.) Merr] grown in soil-less media. Soil Biology and Biochemistry, 34(12), 1953-1957.

Barro, F., Fontes, A. G., and Maldonado, J. M. (1991). Organic nitrogen content and nitrate and nitrite reductase activities in tritordeum and wheat grown under nitrate or ammonium. Plant and Soil, 135(2), 251-256.

Baset,M., Shamsuddin,Z.H., WAhab,Z., AndMarziah,M. (2010). Effect of plant growth promoting rhizobacterial (PGPR) inoculation on growth and nitrogen incorporation of tissue-cultured 'musa' plantlets under nitrogen-free hydroponics condition. Australian Journal of Crop Science, $4(2), 85$.

Bremner, J. M. (1996). Nitrogen-total. In J. M. Bartels and J. M. Bigham (Eds), Methods of soil analysis. Part III. Chemical methods (2nd ed., pp. 1085-1121). Madison WI, USA: ASA SSSA Publisher Agron. No: 5.

Chattha, M. B., Iqbal, A., Chattha, M.U., Hassan, M.U., Khan, I., Ashraf, I., Faisal, M., and Usman, M. (2017). PGPR 1noculated-seed increases the productivity of forage sorghum under fertilized conditions. Australian Journal of Basic and Applied Sciences, 13, 150-153.

Constable, J. V., Bassirirad, H., Lussenhop, J., And Zerinun, A. (2001). Influence of elevated $\mathrm{CO}_{2}$ and mycorrhizae on nitrogen acquisition: Contrasting responses in Pinus taeda and Liquidambar styraciflua. Tree Physiology, 21(2-3), 83-91.

Couillerot, O., Prigent-Combaret, C., CaballeroMellado, J., And MoËnne-Loccoz, Y. (2009). Pseudomonas fluorescens and closely- related fluorescent pseudomonads as biocontrol agents of soil-borne phytopathogens. Letters in Applied Microbiology, 48(5), 505-512.

Cousins, A. B., And Bloom, A. J. (2003). Influence of elevated $\mathrm{CO}_{2}$ and nitrogen nutrition on photosynthesis and nitrate photo-assimilation in maize (Zea mays L.). Plant, Cell \& Environment, 26(9), 1525-1530.

DAs, P. K. (2010). Effect of cyanobacterial biofertilizer on growth and biochemical characteristics of Vinca rosea Linn. Research Journal of Biotechnology, 5(4), 76-79.

De Silva, A., Patterson, K., Rothrock, C., and Moore, J. (2000). Growth promotion of highbush blueberry by fungal and bacterial inoculants. Hortscience, 35(7), 1228-1230.
Evans, J. R. (1989). Photosynthesis and nitrogen relationships in leaves of $\mathrm{C} 3$ plants. Oecologia, 78(1), 9-19.

Fierro-Coronado, R. A., Quiroz-Figueroa, F. R., García-Pérez, L. M., Ramírez-Chávez, E., MolinaTorres, J., And Maldonado-Mendoza, I. E. (2014). IAA-producing rhizobacteria from chickpea (Cicer arietinum L.) induce changes in root architecture and increase root biomass. Canadian Journal of Microbiology, 60(10), 639-648.

Fisher, P. R., Heins, R. D., And Lieth, J. H. (1996). Quantifying the relationship between phases of stem elongation and flower initiation in poinsettia. Journal of the American Society for Horticultural Science, 121, 686-693.

Ge, B., Liu, B., Nwet, T. T., ZhaO, W., Shi, L., And ZHANG, K. (2016). Bacillus methylotrophicus Strain NKG-1, isolated from Changbai Mountain, China, has potential applications as a biofertilizer or biocontrol agent. PLoS ONE, 11(11), e0166079, doi: 10.1371/journal.pone.0166079.

Gebauer, G., Melzer, A., And Rehder, H. (1984). Nitrate content and nitrate reductase activity in Rumex obtusifolius L. Oecologia, 63(1), 136-142.

Geiger, M., Haake, V., Ludewig, F., Sonnewald, U., And Stitt, M. (1999). The nitrate and ammonium nitrate supply have a major influence on the response of photosynthesis, carbon metabolism, nitrogen metabolism and growth to elevated carbon dioxide in tobacco. Plant, Cell \& Environment, 22(10), 1177-1199.

Gholami, A., Shahsavani, S., and Nezarat, S. (2009). The effect of plant growth promoting rhizobacteria (PGPR) on germination, seedling growth and yield of maize. World Academy of Science, Engineering and Technology, 49, 19-24.

Glick,B.R.,Patten, C.L.,Holguin, G., andPenrose, D.M. (1999). Biochemical and genetic mechanisms used by plant growth promoting bacteria (p. 267). London, UK: Imperial College Press.

Han, H. S., And Lee, K. D. (2005). Plant growth promoting rhizobacteria effect on antioxidant status, photosynthesis, mineral uptake and growth of lettuce under soil salinity. Research Journal of Agriculture and Biological Sciences, 1(3), 210-215.

Hawkesford, M., Horst, W., Kichey, T., Lambers, H., Schjoerring, J., Møller, I. S., And White, P. (2012). Functions of macronutrients. In P. Marschner (Ed). Marschner's mineral nutrition of higher plants (pp. 135-189). Pergamon, UK: Academic Press.

Horchani, F., Hajri, R., And Aschi-Smit, S. (2010). Effect of ammonium or nitrate nutrition on photosynthesis, growth, and nitrogen assimilation in tomato plants. Journal of Plant Nutrition and Soil Science, 173(4), 610-617.

Hu, J., Caí, X., And JeOng, B. R. (2019). Silicon affects root development, tissue mineral content, and 
expression of silicon transporter genes in poinsettia (Euphorbia pulcherrima Willd.) Cultivars. Plants 8(6), 180.

Hu, Y. B., Bellaloui, N., Sun, G. Y., Tigabu, M., And WANG, J. H. (2014). Exogenous sodium sulfide improves morphological and physiological responses of a hybrid Populus species to nitrogen dioxide. Journal of Plant Physiology, 171, 868-875.

Jonassen, E. M., Lea, U. S., And Lillo, C. (2008). HY5 and $\mathrm{HYH}$ are positive regulators of nitrate reductase in seedlings and rosette stage plants. Planta, 227(3), 559-564.

Karagöz, H., ÇAKmakçı, R., Hosseinpour, A., And KodAz, S. (2018). Alleviation of water stress and promotion of the growth of sugar beet (Beta vulgaris L.) plants by multi-traits rhizobacteria. Applied Ecology and Environmental Research, 16(5), 68016813.

Karunananda, D. P., and Peiris, S. E. (2011). Evaluation of public acceptability and longevity of forced bloomed poinsettia (Euphorbia pulcherrima) pots in indoor decorations. Journal of Tropical Agriculture Science, 23(1), 21-29.

Kato, Y., Yamamoto, Y., Murakami, S., and Sato, F. (2005). Post-translational regulation of CND41 protease activity in senescent tobacco leaves. Planta, 222, 643-651.

Kokalis-Burelle, N., Vavrina, C. S., Rosskopf, E. N., AND Shelby, R. A. (2002). Field evaluation of plant growth-promoting rhizobacteria amended transplant mixes and soil solarization for tomato and pepper production in Florida. Plant and Soil, 238(2), 257266.

Kotan, R., ÇaKır, A., Ozer, H., Kordali, Ş., ÇAKmakci, R., Dadasoglu, F., Dikbaș, N., Aydin, T., And Kazaz, C. (2014). Antibacterial effects of Origanum onites against phytopathogenicbacteria: Possible use of the extracts from protection of diseasecaused by some phytopathogenic bacteria. Scientia Horticulturae, $172,210-220$.

LAzArovits, G. (1995). Application of growthpromoting rhizobacteria to transplant plug and seed. HortScience, 30(4), 750A-750.

Liu, Z. L., Li, Y. J., Hou, H. Y., Zhu, X. C., Rai, V., He, X. Y., and Tian, C. J. (2013). Differences in the arbuscular mycorrhizal fungi-improved rice resistance to low temperature at two $\mathrm{N}$ levels: Aspects of $\mathrm{N}$ and $\mathrm{C}$ metabolism on the plant side. Plant Physiology and Biochemistry, 71, 87-95.

Macias, F. J., Arías, D. J., Vela, M. D., Solera, R., and Garcia-Morales, J. L. (2010). Substitution of peat for composts of municipal wastes in growing media: Effects on growth and nutrition of Euphorbia pulcherrima. Paper presented at the $14^{\text {th }}$ Ramiran International Conference: Treatment and use of non conventional organic residues in agriculture (Vol. 4). Lisboa, Portugal.
Marschner, H. (1995). Mineral nutrition in higher plants. London, UK: Academic Press.

Martinetti, L., Sparacino, A., Ferrante, A., And Allievi, L. (2007). Effect of a biofertiliser on the growth of poinsettia. Paper presented at the International Symposium on High Technology for Greenhouse System Management: Greensys2007 801 (pp. 1177-1182).

Mishra, R. K., Prakash, O., Alam, M., and Dikshit, A. (2010). Influence of plant growth promoting rhizobacteria (PGPR) on the productivity of Pelargonium graveolens L. Herit. Recent Research in Science and Technology, 2(5), 53-57.

Nguyen, M.L., Spaepen, S., Du Jardin, P., AndDelaplace,P. (2019). Biostimulant effects of rhizobacteria on wheat growth and nutrient uptake depend on nitrogen application and plant development. Archives of Agronomy and Soil Science, 65(1), 58-73.

Parlakova Karagöz, F., Dursun, A., Kotan, R., Ekinci, M., Yildirim, E., And Mohammad, P. (2016). Assessment of the effects of some bacterial isolates and hormones on corm formation and some plant properties in saffron (Crocus sativus L.). Ankara University Journal of Agricultural Sciences, 22(4), 500-511.

Parlakova Karagöz, F., And Dursun, A. (2019a). A study of different bacterial formulations in increasing the nutrient content of bulb and leaf of tulips and grown soil samples. Journal of Horticultural Science \& Ornamental Plants, 11(1), 52-65.

Parlakova Karagöz, F., And Dursun, A. (2019b). Assessment of different pgpr formulations as a biological fertilizer in cultivation of poinsettia (Euphorbia pulcherrima). Frontiers in Environmental Microbiology, 5(2), 48-59.

Parlakova Karagöz, F., And Dursun, A. (2019c). Effects of nitrogen fixing and phosphate solubilizing bacteria on growth and bulbs production of tulip cultivars. Journal of Ege University Faculty of Agriculture, 56 (2), 241-248.

Paul, E. A., And Clark, F. E. (1996). Soil microbiology and biochemistry (273 pp). San Diego, CA, USA: Academic Press Inc.

Pazouki, A. R. (2016). Effects of humic acid and plant growth promoting rhizobacteria (PGPRs) on yield and yield components of durum wheat under drought stress condition in Shahr-e-Rey region. Cereal Research Communications, 6(1), 105-117.

Pillay, V. K., And NowaK, J. (1997). Inoculum density, temperature and genotypeeffects on the in vitro growth promotion and epiphytic and endophyticcolonization of tomato (Lycopersicon esculentum L.) seedlings inoculated with a Pseudomonas bacterium. Canadian Journal of Microbiology, 43, 354-361.

Pourtau, N., Mares, M., Purdy, S., Quentin, N., Ruel, A., AND Wingler, A. (2004). Interactions of abscisic 
acid and sugar signalling in the regulation of leaf senescence. Planta, 219, 765-772.

Rachmawati, D., And Korlina, E. (2016). Kajian penggunaan pupuk hayati untuk mengendalikan penyakit akar gada (Plasmodiophora brassicae) pada tanaman sawi daging. Agrovigor, 9(1), 67-72.

Rojas, A., Holguin, G., Glick, B. R., and Bashan, Y. (2001). Synergism between Phyllobacterium sp. $\left(\mathrm{N}_{2}-\right.$ fixer) and Bacillus licheniformis (P-solubilizer), both from a semiarid mangrove rhizosphere. FEMS Microbiology Ecology, 35(2), 181-187.

Saharan, B. S., and Nehra, V. (2011). Plant growth promoting rhizobacteria: A critical review. Life Sciences and Medicine Research, 21, 1-30.

Shaukat, K., Affrasayab, S., And Hasnain, S. (2006). Growth responses of Helianthus annus to plant growth promoting rhizobacteria used as a biofertilizer. Journal of Agricultural Research, 1, 573-581.

Silva M. I. N. (2011). Potencial de rhizobacterias Pseudomonas putida como biofertilizantes para el crecimiento de plantas de Nochebuena (Euphorbia pulcherrima L.). Veracruzana University Faculty of Agricultural Sciences, Agricultural Engineer, Receptional Experience Work, p. 951. Available at: https://docplayer.es/39281025-Universidadveracruzana-facultad-de-ciencias-agrolas.html

Smart, C. M. (1994). Gene expression during leaf senescence. New Phytologist, 126, 419-448.

SuhAG, M. (2016). Potential of biofertilizers to replace chemical fertilizers. International Advanced Research Journal in Science, Engineering and Technology, 3(5), 163-167.

Taiz, L., and Zeiger, E. (2002). Plant physiology. Sunderland, MA: Sinauer Associates, 700.

Tischner, R. (2000). Nitrate uptake and reduction in higher and lower plants. Plant, Cell \& Environment, 23(10), 1005-1024.

Turan, M., Ekinci, M., Yildirim, E., Güneș, A., Karagöz, K., Kotan, R., And Dursun, A. (2014). Plant growth-promoting rhizobacteria improved growth, nutrient, and hormone content of cabbage
(Brassica oleracea) seedlings. Turkish Journal of Agriculture and Forestry, 38(3), 327-333.

USDA, (2016). Agricultural statistics 2016. (United States Department of Agriculture) and NASS (National Agricultural Statistics Service). Washington, DC, USA.

Vessey, J. K. (2003). Plant growth promoting rhizobacteria as bio fertilizers. Plant and Soil, 255, 571-586.

Vitousek, P. M., and Howarth, R. V. (1991). Nitrogen limitation on land and in the sea: How can it occur? Biogeochemistry, 13, 85-115.

Yu, X. Z., AND ZHANG, F. Z. (2012). Activities of nitrate reductase and glutamine synthetase in rice seedlings during cyanide metabolism. Journal of Hazardous Materials, 225, 190-194.

Zablotowicz, R. M., Tipping, E. M., Lifshitz, R., And Kloepper, J. W. (1991). Plant growth promotion mediated by bacterial rhizosphere colonizers. In D. L. Keister and P. B. Cregan (Eds), The rhizosphere and plant growth (pp. 315-326). Springer, Dordrecht.

Zerrouk, I. Z., Rahmoune, B., Khelifi, L., Mounir, K., Baluska, F., ANd Ludwig-Müller, J. (2019). Algerian Sahara PGPR confers maize root tolerance to salt and aluminum toxicity via ACC deaminase and IAA. Acta Physiologiae Plantarum, 41(6), 91.

Zhang, C. F., Peng, S. B., Peng, X. X., Chavez, A. Q., And Bennett, J. (1997). Response of glutamine synthetase isoforms to nitrogen sources in rice (Oryza sativa L.) roots. Plant Science, 125, 163-170.

Zhang, Y., Liu, Z., Liu, R., Wang, L., AND Bi, Y. (2011). Gibberellins negatively regulate light-induced nitrate reductase activity in Arabidopsis seedlings. Journal of Plant Physiology, 168(18), 2161-2168.

Zulueta-Rodriguez, R., Cordoba-Matson, M. V., Hernandez-Montiel, L. G., Murillo-Amador, B., Rueda-Puente, E., And Lara, L. (2014). Effect of Pseudomonas putida on growth and anthocyanin pigment in two poinsettia (Euphorbia pulcherrima) cultivars. The Scientific World Journal, 2014, Article ID 810192, doi: 10.1155/2014/810192.

Received March 30, 2020; accepted August 14, 2020 